\title{
UJI AKTIVITAS ANTIOKSIDAN DAN ANTIBAKTERI EKSTRAK METANOL ALGA MERAH Eucheuma spinosum DARI PERAIRAN WONGSOREJO BANYUWANGI
}

\author{
Ahmad Hanapi, A. Ghanaim Fasya, Ulfatul Mardiyah dan Miftahurrahmah \\ Jurusan Kimia, Fakultas Sains dan Teknologi UIN Maulana Malik Ibrahim Malang
}

\begin{abstract}
Antioxidant and antibacterial activity assay and active compound identification red algae Euchema spinosum extract was conducted. Active compound extraction was conducted using maceration method with methanol. Antioxidant activity assay using DPPH method with determining $\mathrm{EC}_{50}$ value. Antibacterial activity assay using diffusion method toward Staphylococcus aureus and Escherichia coli bacteria. The results show that antioxidant activity of Eucheuma spinosum methanol extract has $\mathrm{EC}_{50}$ value $22.13 \mathrm{ppm}$. Antibacterial activity toward Staphylococcus aureus and Escherichia coli bacteria had inhibitation in $80 \mathrm{mg} / \mathrm{mL}$ concentration at the amount of $4 \mathrm{~mm}$ and $3 \mathrm{~mm}$ respectively. The result of phytochemical essay shows that compounds which discoveried in Eucheuma spinosum methanol extract were flavonoids, triterpenoids and ascorbic acid.
\end{abstract}

Keywords: Eucheuma spinosum, Antioxidant activity, DPPH, antibacterial activity, E. coli, S. aureus.

\begin{abstract}
ABSTRAK
Telah dilakukan pengujian aktivitas antioksidan, antibakteri dan identifikasi senyawa aktif ekstrak metanol alga merah Eucheuma spinosum. Ekstraksi senyawa aktif dilakukan dengan metode maserasi menggunakan metanol. Pengujian aktivitas antioksidan menggunakan metode $\mathrm{DPPH}$ dengan menentukan nilai $\mathrm{EC}_{50}$, sedangkan pengujian aktivitas antibakteri menggunakan metode difusi cakram terhadap bakteri Staphylococcus aureus dan Escherichia coli. Hasil penelitian menunjukkan bahwa aktivitas antioksidan ekstrak metanol Eucheuma spinosum tergolong sangat kuat dengan nilai $\mathrm{EC}_{50}$ 22,13 ppm, sedangkan aktivitas atibakterinya terhadap bakteri Staphylococcus aureus dan Escherichia coli tergolong lemah dengan daya hambat pada konsentrasi $80 \mathrm{mg} / \mathrm{mL}$ secara berturut-turut sebesar $4 \mathrm{~mm}$ dan $3 \mathrm{~mm}$. Uji fitokimia ekstrak metanol alga merah E. spinosum menunjukkan adanya kandungan golongan senyawa flavonoid, triterpenoid dan asam askorbat.
\end{abstract}

Kata Kunci: Eucheuma spinosum, aktivitas antioksidan, DPPH, aktivitas antibakteri, E. coli, S. aureus.

\section{PENDAHULUAN}

Indonesia merupakan Negara bahari dengan keanekaragaman hayati laut terbesar di dunia yang memiliki total luas perairan Nusantara seluas 2,8 juta $\mathrm{Km}^{2}$, dan laut teritorial seluas 0,3 juta $\mathrm{Km}^{2}$.' Indonesia mempunyai luas daratan sekitar 1,9 juta $\mathrm{Km}^{2}$, panjang garis pantai lebih dari 81.000 $\mathrm{Km}$ dan jumlah pulau lebih dari 18.000 pulau. Laut beserta kawasan pesisir Indonesia mempunyai manfaat dan potensi ekonomi (pembangunan) yang sangat besar dan beraneka ragam (Kusumastanto, 2011).

Salah satu potensi biota laut perairan Indonesia adalah makro alga atau dikenal dalam perdagangan sebagai rumput laut. Saat ini sudah ditemukan 555 jenis alga yang berdasarkan kandungan pigmennya dikelompokkan menjadi 4 kelas, yakni : Rhodophyceae, Phaeophyceae, Chlorophyceae, Cyanophyceae. Salah satu alga dari kelas Rhodophyceae adalah Eucheuma spinosum. Alga merah ini mempunyai talus yang keras, silindris dan berdaging (Romimohtarto dan Juwana, 1999).

Alga, baik yang liar maupun yang telah dibudidayakan secara tradisional digunakan sebagai obat diet (Wibowo, 2001), bahan makanan dan obat-obatan, karena kaya akan protein, lipid, vitamin dan mineral yang sangat penting bagi manusia. Temuan terakhir membuktikan bahwa rumput laut berpotensi sebagai antivirus (Manilal et al., 2009), antibakteri (Izzati, 2007), antijamur (Khazanda et al., 2007), antitumor (Zandi et al., 2010) dan antioksidan (Lestario dkk., 2008).

Faten et al. (2009) mengekstrak alga merah Gracilaria verrucosa menggunakan pelarut etanol $70 \%$ kemudian dipartisi menggunakan etil asetat, $n$-butanol dan 
petroleum eter, didapatkan bahwasanya fraksi etil asetat dan petroleum eter merupakan fraksi yang cukup aktif dalam menghambat radikal bebas menggunakan DPPH. Selain itu, Suryaningrum dkk. (2006) mengekstrak rumput laut segar dan kering dari Halmenia harveyana dan Eucheuma cottoni yang tergolong dalam kelas Rhodophceae dengan pelarut metanol p.a kemudian dipartisi dengan $200 \mathrm{~mL}$ campuran metanol : $n$-heksana (2:3) lalu diuji aktivitas antioksidannya dengan metode DPPH, dan didapatkan ekstrak rumput laut segar memiliki aktivitas antioksidan tertinggi.

Iskandar (2009) melakukan penelitian uji aktivitas antibakteri ekstrak etanol alga merah jenis Eucheuma cottonii. Hasil penelitian menunjukkan bahwa ekstrak etanol alga merah memiliki aktivitas antibakteri terhadap bakteri uji dengan Konsentrasi Hambat Minimum (KHM) terhadap bakteri Bacillus cereus adalah 0,1 $\%$ dan terhadap Escherichia coli adalah 0,5 $\%$. Sedangkan Enida (2011) melakukan penelitian uji aktivitas antibakteri ekstrak $n$ heksan, etil asetat dan etanol pada alga coklat Sargassum polycystum C.Agardh terhadap bakteri Staphylococcus aureus dan Escherichia coli. Hasil penelitian menunjukkan bahwa ekstrak etil asetat alga coklat memiliki kemampuan menghambat pertumbuhan bakteri $S$. aureus dengan daya hambat pada konsentrasi $70 \mathrm{mg} / \mathrm{mL}$ yaitu $14,78 \mathrm{~mm}$ dan konsentrasi $50 \mathrm{mg} / \mathrm{mL}$ yaitu 14,39 untuk bakteri E. coli. Sedangkan KHM bakteri $S$. aureus pada konsentrasi 30 $\mathrm{mg} / \mathrm{mL}$ yaitu $8,24 \mathrm{~mm}$ dan bakteri $E$. coli pada konsentrasi $20 \mathrm{mg} / \mathrm{mL}$ yaitu 9,76 mm.

Sebagai salah satu upaya untuk mengungkapkan sifat biologis dan medis dari flora laut serta untuk mengoptimalkan pemanfaatan bahan alam laut Indonesia, khususnya di daerah Banyuwangi maka pada penelitian ini dilakukan ekstraksi senyawa aktif pada alga merah Eucheuma spinosum dengan pelarut metanol, kemudian dilanjutkan dengan pengujian aktivitas antioksidan terhadap DPPH dan antibakteri menggunakan metode difusi cakram serta mengidentifikasi senyawa yang berkhasiat sebagai antioksidan dan antibakteri dalam alga merah E. spinosum yang berasal dari perairan laut Banyuwangi.

\section{METODE PENELITIAN}

\section{Alat dan Bahan}

Alat-alat yang digunakan dalam penelitian ini adalah pisau, oven, blender, ayakan, desikator, neraca analitik, erlenmeyer, rotary evaporator, corong Buchner, hot plate dan magnetic stirrer, spektrofotometer Uv-Vis, autoklaf, jarum ose, tabung reaksi, beker gelas, inkubator, dan cawan petri.

Bahan sampel yang digunakan dalam penelitian ini adalah alga merah jenis (Eucheuma spinosum) berasal dari laut Wongsorejo Banyuwangi.

Bahan-bahan kimia yang digunakan adalah metanol, DPPH, kalium kromat, kloroform, $\mathrm{BHT}, \mathrm{HCl}$, etanol, $\mathrm{H}_{2} \mathrm{SO}_{4}$ pekat, natrium bikarbonat, asam asetat anhidrida, pereaksi Mayer dan Dragendorff, $\mathrm{AgNO}_{3}$, serbuk logam $\mathrm{Mg}$, nutrien agar, penisilin, sterptomicin, DMSO, kertas saring, kapas dan $\mathrm{pH}$ indikator universal.

\section{Prosedur Penelitian}

Uji Taksonomi

Uji taksonomi alga merah $E$. spinosum dilakukan secara kualitatif di daerah perairan Wongsorejo Banyuwangi dan di Jurusan Biologi UIN Maulana Malik Ibrahim Malang.

\section{Preparasi Sampel}

Alga merah E. spinosum sebanyak 3 $\mathrm{Kg}$ dicuci dengan air, kemudian diiris kecilkecil lalu dioven pada suhu $30-38{ }^{\circ} \mathrm{C}$ selama 24 jam dan dihaluskan menggunakan blender hingga didapatkan serbuk alga merah E. Spinosum.

\section{Penentuan Kadar Air Secara Thermo- gravimetri (AOAC, 1984)}

Pada penentuan kadar air, disiapkan cawan porselen terlebih dahulu, lalu dipanaskan dalam oven pada suhu $105{ }^{\circ} \mathrm{C}$ sekitar 15 menit untuk menghilangkan 
kadar airnya. Kemudian cawan disimpan dalam desikator sekitar 10 menit, lalu ditimbang dan dilakukan perlakuan yang sama sampai diperoleh berat cawan yang konstan. Setelah itu, sebanyak 5 gram sampel dimasukkan dalam cawan porselen, kemudian dimasukkan dalam oven dan dikeringkan pada suhu $105{ }^{\circ} \mathrm{C}$ selama \pm 15 , kemudian sampel disimpan dalam desikator sekitar \pm 10 menit dan ditimbang. Sampel tersebut dipanaskan kembali dalam oven \pm 15 menit, didinginkan dalam desikator dan ditimbang kembali. Perlakuan ini diulangi sampai berat konstan. Kadar air dalam alga merah E. spinosum dihitung menggunakan persamaan berikut (AOAC, 1984):

$$
\text { Kadar air }=\frac{(b-c)}{(b-a)} \times 100 \%
$$

Dimana :

$\mathrm{a}=$ bobot cawan kosong

$\mathrm{b}=$ bobot sampel + cawan sebelum dikeringkan

$\mathrm{c}=$ bobot cawan + sampel setelah dikeringkan

\section{Penentuan Kadar Garam}

Sampel ditimbang sebanyak 5 gram dan diekstrak dengan menggunakan akuades panas $10 \mathrm{~mL}$, ditunggu beberapa lama sehingga semua garam $(\mathrm{NaCl})$ larut, ekstraksi diulang beberapa kali (8-10 kali). Ekstrak diambil sebanyak $5 \mathrm{~mL}$ lalu dimasukkan ke dalam erlenmeyer, setelah itu ditambahkan dengan kalium kromat 5\% $3 \mathrm{~mL}$ dan dititrasi dengan $\mathrm{AgNO}_{3}$ 0,1 N sampai warna menjadi merah bata. Perhitungan kadar garam $(\mathrm{NaCl})$ menggunakan persamaan berikut (Sudarmadji dkk., 2007):

$\% \mathrm{NaCl}=$

$$
\frac{\mathrm{mL} \mathrm{AgNO}_{3} \times \mathrm{N} \mathrm{AgNO}_{3} \times 58,5}{\text { massa sampel } \times 1000} \times 100 \%
$$

\section{Ekstraksi Alga Merah Eucheuma spinosum}

Ekstraksi komponen aktif dilakukan dengan cara ekstraksi maserasi atau perendaman. Alga merah yang telah dikeringkan ditimbang sebanyak $100 \mathrm{~g}$ dan diekstraksi secara maserasi menggunakan $300 \mathrm{~mL}$ pelarut metanol selama 24 jam dan dilakukan pengocokan menggunakan shaker dengan kecepatan $150 \mathrm{rpm}$ (rotation per minutes), setelah itu dilakukan penyaringan menggunakan corong Buchner. Ampas yang diperoleh dimaserasi kembali menggunakan pelarut yang sama sebanyak 3 kali pengulangan dengan perlakuan yang sama hingga filtrar yang dihasilkan bening, setelah itu dilakukan penyaringan. Ketiga filtrat yang diperoleh digabung menjadi satu. Kemudian ekstrak yang diperoleh dipekatkan menggunakan rotary evaporator. Ekstrak pekat yang diperoleh ditimbang lalu dihitung rendemen ekstrak dengan Persamaan berikut:

$\%$ Rendemen $=\frac{\text { Berat ekstrak }}{\text { Berat sampel }} \quad$ x $100 \%$ dan dilanjutkan dengan pengujian aktivitas antioksidan dan antibakteri.

\section{Uji Aktivitas Antioksidan Penentuan Panjang Gelombang Maksimum}

Larutan DPPH 0,2 $\mathrm{mM}$ sebanyak 3 $\mathrm{mL}$ dimasukkan ke dalam tabung reaksi didiamkam \pm 10 menit. Kemudian dimasukkan ke dalam kuvet hingga penuh. Dicari $\lambda_{\text {maks }}$ larutan dan dicatat hasil pengukuran $\lambda_{\text {maks }}$ untuk digunakan pada tahap selanjutnya (Rahayu, dkk., 2010).

\section{Penentuan Waktu Kestabilan Pengukuran Antioksidan}

Dibuat larutan ekstrak 100 ppm sebanyak $25 \mathrm{~mL}$, kemudian diambil sebanyak 2,25 mL. Ditambahkan 0,2 mM larutan DPPH sebanyak 0,75 mL, kemudian dicari waktu kestabilan setelah inkubasi dan sebelum inkubasi pada rentangan waktu 5 50 menit dengan interval 5 menit. Sampel diukur pada $\lambda_{\text {maks }}$ dan waktu kestabilan yang telah didapatkan.

\section{Pengukuran Potensi Antioksidan Pada Sampel}


a) Absorbansi kontrol: Larutan DPPH dengan konsentrasi $0,2 \mathrm{mM}$ sebanyak 3 $\mathrm{mL}$ dimasukkan ke dalam tabung reaksi, lalu diinkubasi pada suhu $37{ }^{\circ} \mathrm{C}$ selama waktu kestabilan yang telah didapatkan pada tahap sebelumnya, setelah itu larutan dimasukkan ke dalam kuvet hingga penuh dan diukur absorbansinya dengan $\lambda_{\text {maks }}$ yang didapatkan.

b) Ekstrak pekat Eucheuma spinosum, dilarutkan dalam metanol dengan konsentrasi 1, 5, 25, 50, 100, 150, dan 200 ppm. Disiapkan tabung reaksi kemudian diisi dengan 2,25 mL ekstrak dan ditambahkan DPPH sebanyak 0,75 $\mathrm{mL}$ dengan konsentrasi $0,2 \mathrm{mM}$ dalam etanol $95 \% \mathrm{v} / \mathrm{v}$ (perbandingan larutan DPPH : ekstrak 1:3). Setelah itu diinkubasi dengan suhu $37{ }^{\circ} \mathrm{C}$ pada waktu kestabilan yang didapatkan pada tahap sebelumnya, kemudian dimasukkan ke dalam kuvet hingga penuh untuk mengukur absorbansinya pada $\lambda_{\text {maks }}$. Data absorbansi (A) yang diperoleh dari masing-masing ekstrak dihitung nilai persen (\%) aktivitas antioksidannya. Nilai tersebut diperoleh dengan persamaan berikut (Arindah, 2010):

$$
\begin{aligned}
& \% \text { Aktivitas } \\
& \text { antioksidan }
\end{aligned}=\left(\frac{\text { A kontrol }- \text { A sampel }}{\text { A kontrol }}\right) \times 100 \%
$$

\section{Uji Aktivitas Antibakteri \\ Sterilisasi Alat dan Bahan}

Sterilisasi alat dan bahan dengan cara menutup alat-alat yang akan disterilkan dengan alumunium foil atau kapas. Dimasukkan ke dalam autoklaf dan diatur pada suhu $121{ }^{\circ} \mathrm{C}$ dengan tekanan 15 psi (per square inchi). Sterilisasi dilakukan untuk alat selama 30 menit dan bahan selama 15 menit (Irianto, 2006). Alat-alat yang tidak tahan terhadap panas tinggi disterilkan dengan menggunakan etanol 70 $\%$ (Volk dan Wheeler, 1993).

\section{Pembuatan Media}

Media yang disiapkan adalah media padat agar (Nutrient Agar) miring untuk peremajaan biakan murni dan uji antibakteri senyawa hasil reaksi pada bakteri Escherichia coli dan Staphylococcus aureus. Media cair (Nutrient Broth) untuk pembuatan larutan inokulum bakteri $S$. aureus dan E. coli. Pembuatan media padat dilakukan dengan cara sebanyak 2 gram nutrien agar dilarutkan dalam $100 \mathrm{~mL}$ akuades dalam beaker glass dan dimasukkan dalam erlenmeyer dan ditutup kapas. Selanjutnya, suspensi dipanaskan hingga mendidih lalu dimasukkan ke dalam tabung reaksi (masing-masing $7 \mathrm{~mL}$ untuk peremajaan biakan murni dan $10 \mathrm{~mL}$ untuk media uji aktivitas antibakteri) (Zamrodi, 2011). Proses ini dilakukan secara aseptis dengan cara bagian ujung alat dipanaskan dan ditutup dengan kapas dan alumunium foil. Media NA disterilkan dalam autoklaf dan diatur pada suhu $121{ }^{\circ} \mathrm{C}$ selama 15 menit, kemudian media untuk peremajaan diletakkan dalam posisi miring dan didiamkan pada suhu ruang sampai media memadat.

Media cair (Nutrient Broth) dibuat dengan cara sebanyak 1 gr Nutrient Broth (NB) dilarutkan dalam $125 \mathrm{~mL}$ aquades, kemudian dimasukkan dalam erlenmeyer dan ditutup dengan kapas. Selanjutnya, suspensi dipanaskan sampai mendidih, kemudian didinginkan dalam suhu ruang. Selanjutnya, media disterilkan dalam autoklaf selama 15 menit pada suhu $121^{\circ} \mathrm{C}$ dan tekanan 15 psi (per square inchi) (Volk dan Wheeler, 1993).

\section{Peremajaan Biakan Murni S. aureus dan E. coli}

Biakan murni $S$. aureus dan E. coli digoreskan secara aseptis dengan jarum ose pada media padat agar miring dan tabung media ditutup dengan kapas. Media tersebut diinkubasi selama 48 jam pada suhu $37{ }^{\circ} \mathrm{C}$ di dalam inkubator. Kemudian diletakkan dalam lemari pendingin. 
Pembuatan Larutan Biakan Aktif Bakteri S. aureus dan E. coli

Satu ose bakteri hasil peremajaan biakan murni $S$. aureus dan E. coli dibiakkan dalam $10 \mathrm{~mL}$ media cair (NB) steril dan dihomogenkan. Larutan ini berfungsi sebagai biakan aktif.

\section{Uji Aktivitas Antibakteri}

Media padat $10 \mathrm{~mL}$ yang telah dipanaskan hingga mencair, didinginkan sampai suhu $40{ }^{\circ} \mathrm{C}$, dan dituang dalam cawan petri steril. Ditambahkan $0,1 \mathrm{~mL}$ larutan biakan aktif bakteri Staphylococcus aureus dan Escherichia coli dihomogenkan. Dibiarkan hingga memadat. Kertas cakram (diameter $5 \mathrm{~mm}$ ) diresapkan dalam ekstrak alga merah E. spinosum dan kontrol. Proses peresapan dilakukan dengan cara meneteskan $20 \mu \mathrm{L}$ kontrol positif (penisilin dan streptomisin), kontrol negatif (pelarut) dan larutan ekstrak (Zakaria et al., 2007). Kertas cakram tersebut diletakkan di atas permukaan media bakteri menggunakan pinset dan ditekan sedikit. Media bakteri yang sudah diberi bahan antibakteri diinkubasi pada suhu $37{ }^{\circ} \mathrm{C}$ selama 24 jam dalam inkubator. Diameter zona hambatan yang terbentuk diukur menggunakan penggaris untuk menentukan efektivitas antibakteri (Volk dan Wheeler, 1993). Diameter zona hambat adalah diameter yang tidak ditumbuhi bakteri di sekitar kertas cakram dikurangi diameter kertas cakram.

Uji antibakteri dilakukan dengan cara memvariasi konsentrasi yaitu pada kosentrasi ekstrak sebesar 30, 40, 50, 60, 70 , dan $80 \mathrm{mg} / \mathrm{mL}$ ). Kemudian dilakukan pengulangan uji antibakteri pada masingmasing konsentrasi sebanyak tiga kali. Pada penelitian ini kontrol positif penisilin (konsentrasi $25 \mathrm{mg} / \mathrm{mL}$ ) digunakan untuk bakteri Staphylcoccus aureus (gram positif) sedangkan kontrol positif streptomisin (konsentrasi 6,25 mg/mL) digunakan untuk bakteri Escherichia coli (gram negatif) (Soetan, et.al, 2006).

\section{Identifikasi Golongan Senyawa Aktif Identifikasi Flavonoid}

Ekstrak kasar $5 \mathrm{mg}$ ditambahkan dengan air panas 1-2 $\mathrm{mL}$ air panas dan sedikit serbuk Mg. Kemudian ditambahkan 4-5 tetes $\mathrm{HCl} 37 \%$ dan etanol $95 \%$ dengan volume yang sama lalu dikocok. Jika menunjukkan warna merah, kuning atau jingga maka ekstrak kasar positif mengandung flavonoid (Febriany, 2004).

\section{Identifikasi Alkaloid}

Ekstrak kasar dimasukkan dalam tabung reaksi, ditambah $0,5 \mathrm{~mL} \mathrm{HCl} 2 \%$ dan larutan dibagi dalam dua tabung. Tabung I ditambahkan 2-3 tetes reagen Dragendorff, tabung II ditambahkan 2-3 tetes reagen Mayer. Jika tabung I terbentuk endapan jingga dan pada tabung II terbentuk endapan kekuning-kuningan, menunjukkan adanya alkaloid.

\section{Identifikasi Steroid}

Ekstrak kasar diambil $5 \mathrm{mg}$ dilarutkan dalam 2-3 mL kloroform, lalu ditambahkan 10 tetes asam asetat anhidrida dan 2-3 tetes $\mathrm{H}_{2} \mathrm{SO}_{4}$ pekat melalui dinding tabung, jika terbentuk warna biru sampai hijau menunjukkan adanya steroid, sedangkan jika hasil yang diperoleh berupa cincin kecoklatan atau violet pada perbatasan dua pelarut menunjukkan adanya triterpenoid (Auterhoff, dkk., 1987).

\section{Uji Triterpenoid}

Ekstrak alga merah E. spinosum dimasukkan dalam tabung reaksi, dilarutkan dalam $0,5 \mathrm{~mL}$ kloroform lalu ditambah dengan $0,5 \mathrm{~mL}$ asam asetat anhidrat. Campuran ini selanjutnya ditambah dengan 1-2 $\mathrm{mL} \quad \mathrm{H}_{2} \mathrm{SO}_{4}$ pekat melalui dinding tabung tersebut. Jika hasil yang diperoleh berupa cincin kecoklatan atau violet pada perbatasan dua pelarut menunjukkan adanya triterpenoid dalam sampel (Indrayani, dkk., 2006). 


\section{HASIL DAN PEMBAHASAN Preparasi Sampel}

Alga merah Eucheuma spinosum dicuci hingga bersih untuk menghilangkan pasir maupun lumpur yang menempel pada tallusnya. Setelah benar-benar bersih, alga merah E. spinosum dioven pada suhu $38{ }^{\circ} \mathrm{C}$ selama 24 jam. Tujuan pengeringan ini untuk meminimalisir kadar air yang terkandung dalam alga merah E. spinosum dan untuk menghambat aktivitas mikroorganisme (jamur maupun bakteri) agar dapat disimpan dalam jangka waktu yang cukup lama. Pengeringan sampel dilakukan pada suhu $38{ }^{\circ} \mathrm{C}$ agar senyawa aktif yang terkandung dalam sampel alga merah $E$. spinosum tidak rusak karena suhu yang terlalu tinggi.

Alga merah yang sudah kering dipotong kecil-kecil lalu diblender hingga halus, dan disaring menggunakan penyaring (ayakan) dengan ukuran 60-250 mesh. Tujuan penghalusan sampel yaitu untuk memperbesar ukuran permukaan sampel sehingga proses ekstraksi berjalan optimal karena semakin luas permukaan sampel maka interaksi antara pelarut dan sampel semakin besar. Hasil yang diperoleh dari proses ini menunjukkan bahwa dari $4 \mathrm{Kg}$ sampel basah didapatkan serbuk $E$. spinosum sebanyak 350 gram. Selain itu, serbuk alga merah E. spinosum berwarna coklat dan berbau menyengat.

\section{Penentuan Kadar Air}

Penentuan kadar air bertujuan untuk mengetahui kadar air dalam sampel alga merah E. spinosum yang dapat mempengaruhi proses ekstraksi dan meminimalkan kerusakan akibat degradasi oleh mikroorganisme maupun penguraian oleh enzim pada proses penyimpanan sampel. Kadar air dalam alga merah $E$. spinosum ditentukan dengan proses penguapan menggunakan oven pada suhu $105{ }^{\circ} \mathrm{C}$ hingga berat sampel konstan. Selisih berat sampel sebelum dan sesudah pengeringan menunjukkan banyaknya air yang diuapkan. Kandungan air rumput laut segar sama seperti tanaman pada umumnya yaitu berkisar antara $80-90 \%$ dan setelah pengeringan menjadi $10-20 \%$ (Astawan, et al. 2001). Kadar air alga merah E. spinosum sebelum maupun setelah dikeringkan dapat dilihat pada Tabel 1.

Tabel 1 Kadar air dalam alga merah $E$. spinosum

\begin{tabular}{c|c}
\hline Sampel & Kadar Air (\%) \\
\hline E. spinosum basah & 79,996 \\
E. spinosum kering & 9,947 \\
\hline
\end{tabular}

Kandungan kadar air pada alga merah

E. Spinosum basah cukup tinggi, yaitu sebesar 79,96 \%. Oleh karena itu perlu dilakukan proses pengeringan sebelum sampel alga merah E. spinosum dimaserasi agar tidak mengganggu proses ekstraksi. sampel alga merah E. spinosum setelah pengeringan memiliki nilai kadar air yang lebih rendah daripada kadar air maksimum yang disyaratkan yakni 9,947 \% . Hal ini menunjukkan bahwa sampel memiliki kadar air yang cukup baik untuk dilakukan proses ekstraksi, karena semakin rendah nilai kadar air bahan maka akan semakin memudahkan pelarut untuk mengekstrak komponen senyawa aktif yang diinginkan. Setyowati (2009) menyatakan bahwa kadar air maksimum yang disyaratkan agar proses ekstraksi dapat berjalan lancar yaitu sebesar $11 \%$.

\section{Penentuan Kadar Garam}

Pada penentuan kadar garam dilakukan untuk mengetahui besarnya kandungan garam dalam sampel yang akan dianalisis. Pada penelitian uji antibakteri ini kadar garam sangat berpengaruh karena kadar garam tinggi dalam suatu sampel maka akan dapat menjadi faktor penghambat pertumbuhan bakteri uji. Uji kadar garam dilakukan menggunakan salinometer Atago PAL-06S refraktometer. Prinsip alat ini berdasarkan pembiasan sinar, dipakai untuk menentukan indeks bias cairan dan mengukur kadar/konsentrasi bahan terlarut dengan memanfaatkan reaksi cahaya. Semakin besar kandungan garam yang terlarut maka menyebabkan indek refraktif larutan semakin besar. Garam $(\mathrm{NaCl})$ memiliki indek bias $=1,544$ terhadap cahaya kuning natrium. 
Hasil pengukuran kadar garam alga merah E. spinosum ditunjukkan pada Tabel 2.

Tabel 2 Kadar garam alga merah E.spinosum

\begin{tabular}{c|c}
\hline Sampel & Kadar Garam (\%) \\
\hline E. spinosum basah & 2 \\
E. spinosum kering & 11,5 \\
\hline
\end{tabular}

Kadar garam alga merah E. spinosum basah lebih kecil daripada alga merah $E$. Spinosum kering dikarenakan pada sampel basah masih banyak mengandung air. Sedangkan pada sampel kering kadar air sudah terkurangi sehingga kadar garam meningkat.

Pada umumnya konsentrasi $10-15 \%$ sudah cukup untuk membunuh sebagian besar jenis-jenis bakteri (Hudaya dan Darajat, 1980). S. aureus masih mungkin tumbuh pada beberapa produk dengan kadar garam agak tinggi yaitu sampai 7$10 \%$. S. aureus akan dihambat pertumbuhannya pada konsentrasi garam 15-20\% dan $\mathrm{pH}$ dibawah 4,5-5 (Rahayu, dkk., 1992). Sedangkan E. coli akan dihambat pertumbuhannya pada konsentrasi garam 13\% (Rosida, dkk., 2007). Jadi pada penelitian ini, bakteri uji $S$. aureus (gram positif) dan E. coli (gram negatif) kemungkinan tidak terhambat pertumbuhannya dengan kadar garam $11,5 \%$.

\section{Ekstraksi Senyawa Aktif Alga Merah $E$.} spinosum

Ekstraksi senyawa aktif alga merah $E$. spinosum menggunakan metode maserasi dengan pelarut metanol. Metode maserasi dipilih karena metode ini menguntungkan dalam isolasi bahan alam karena dengan perendaman, sampel tumbuhan akan mengalami pemecahan dinding dan membran sel akibat perbedaan tekanan antara di dalam dan di luar sel sehingga metabolit sekunder yang ada dalam sitoplasma akan terlarut dalam pelarut. Maserasi dilakukan selama 24 jam menggunakan shaker dengan kecepatan 150 rpm (rotation per minutes) untuk mempercepat kontak antara sampel dengan pelarut. Selanjutnya dilakukan penyaringan dan diperoleh filtrat berwarna hijau tua. Berat sampel yang digunakan ialah 100 gram dalam $300 \mathrm{~mL}$. Maserasi dilakukan pengulangan sebanyak 5 kali sampai filtrat berwarna bening.

$\begin{array}{lcr}\text { Ekstrak } & \text { metanol } & \text { kemudian } \\ \text { dipekatkan } & \text { menggunakan } & \text { rotary } \\ \text { evaporator, } & \text { proses pemekatan ini }\end{array}$ dihentikan ketika pelarut sudah tidak menetes lagi ke dalam labu alas bulat. Ekstrak pekat yang diperoleh kemudian dialiri gas $\mathrm{N}_{2}$ agar sisa-sisa pelarut yang masih terdapat dalam ekstrak dapat dihilangkan. Hasil penelitian menunjukkan ekstrak metanol (filtrat) pada pengulangan 1 dan 2 berwarna hijau pekat, sedangkan pada pengulangan ekstraksi yang ke-3 sampai ke-5 ekstrak metanol (filtrat) berwarna hijau kekuningan dan bening. Hasil ekstraksi dengan pelarut metanol ditunjukkan pada Tabel 3 .

Tabel 3 Rendemen hasil ekstraksi dengan pelarut metanol

\begin{tabular}{ll}
\hline Ekstrak Kasar & Rendemen $\mathbf{( \% )}$ \\
\hline Metanol 1 & 16,86 \\
Metanol 2 & 16,60 \\
Metanol 3 & 15,29 \\
\hline Rata-rata & $\mathbf{1 6 , 2 5}$ \\
\hline
\end{tabular}

Nilai rendemen yang didapatkan pada penelitian ini cukup tinggi yaitu 16,256 \% . Hal itu disebabkan metabolit sekunder yang terdapat dalam sampel alga merah $E$. spinosum cukup banyak. Hasil ini lebih baik daripada penelitian Maulida (2007) menyebutkan bahwa nilai rendemen alga hijau Caulerpa lentillifera kering dan basah hasil ekstraksi maserasi dengan pelarut metanol masing-masing sebesar 7,84\% dan $3,06 \%$.

\section{Uji Aktivitas Antioksidan Dengan Metode 1,1-difenil-2-pikrilhidrazil \\ Pengukuran potensi antioksidan pada} sampel dilakukan dengan berbagai konsentrasi sampel yakni 200, 150, 100, 50, 25, 5 dan 1 ppm, selanjutnya diukur serapannya pada panjang gelombang 515 nm dengan waktu kestabilan yang sudah ditentukan. Pengukuran aktivitas 
antioksidan tiap-tiap konsentrasi pada sampel harus menggunakan larutan kontrol yang berupa larutan DPPH $0,2 \mathrm{mM}$. Larutan DPPH kontrol digunakan untuk memberikan kestabilan pada saat pengukuran aktivitas antioksidan pada sampel (Arindah, 2010). Menurut Molyneux (2003) nilai absorbansi kontrol dapat berkurang dari hari ke hari dikarenakan kehilangan aktivitasnya saat dalam stok larutan DPPH, tetapi nilai absorbansi kontrol tetap dapat memberikan baseline untuk pengukuran saat itu.

Absorbansi kontrol maupun absorbansi sampel yang diperoleh selanjutnya digunakan untuk menentukan persen (\%) aktivitas antioksidan. Persen (\%) aktivitas antioksidan merupakan salah satu parameter yang menunjukkan kemampuan suatu antioksidan dalam menghambat radikal bebas. Semakin tinggi persen (\%) aktivitas antioksidan menunjukkan banyaknya atom hidrogen yang diberikan senyawa aktif kepada radikal DPPH sehingga tereduksi menjadi DPPH-H (1,1-difenil-2-pikrilhidrazin) (Rahayu, et al., 2010). Banyaknya atom hidrogen yang didonorkan oleh molekul antioksidan dapat diketahui secara kualitatif dengan terjadinya perubahan warna radikal DPPH dari ungu menjadi kuning. Hasil pengukuran ekstrak metanol E. spinosum ketika ditambahkan larutan DPPH tidak mengalami perubahan warna dari ungu menjadi kuning, melainkan hanya terjadi pemudaran warna dari ungu menjadi pink keunguan.

Pengujian antioksidan pada ekstrak metanol E. spinosum dibandingkan dengan antioksidan yang sudah ada yaitu BHT dan asam askorbat. Penggunaan pembanding untuk mengetahui seberapa kuat potensi antioksidan yang ada pada ekstrak $E$. spinosum jika dibandingkan dengan antioksidan sintetik yang sudah sering dipakai seperti BHT dan asam askorbat. Apabila \% aktivitas antioksidan sampel sama atau mendekati nilai aktivitas antioksidan pembanding maka dapat dikatakan bahwa sampel berpotensi sebagai salah satu alternatif antioksidan (Yuliani, 2010).

Persen (\%) aktivitas antioksidan yang diperoleh selanjutnya dianalisis menggunakan persamaan regresi non linear menggunakan GraphPad prism5 software, Regression for analyzing dose-response data, sehingga nantinya didapatkan nilai $\mathrm{EC}_{50}$ dari sampel. $\mathrm{EC}_{50}$ (Effective concentration) merupakan parameter yang menunjukkan konsentrasi ekstrak uji yang mampu menangkap radikal sebanyak $50 \%$. Semakin kecil nilai $\mathrm{EC}_{50}$ suatu senyawa uji maka senyawa tersebut semakin aktif sebagai penangkap radikal bebas atau antioksidan. Dengan kata lain $\mathrm{EC}_{50}$ merupakan konsentrasi yang dibutuhkan untuk menurunkan sebesar $50 \%$ dari konsentrasi substrat (radikal DPPH). Nilai $\mathrm{EC}_{50}$ ekstrak metanol E. spinosum ditunjukkan pada Tabel 4.

Tabel 4 Nilai EC $_{50}$ ekstrak metanol $E$. spinosum

\begin{tabular}{l|c}
\hline Ekstrak & $\begin{array}{c}\text { Nilai EC } \\
\text { (mg/L) }\end{array}$ \\
\hline Metanol & 22,13 \\
Vitamin C & 3,702 \\
BHT & 38,25 \\
\hline \multicolumn{2}{|c}{ Tabel 4 menunjukkan bahwa nilai }
\end{tabular}

$\mathrm{EC}_{50}$ ekstrak metanol adalah 22,13 ppm. Aktivitas antioksidan ekstrak metanol tergolong sangat kuat karena memiliki nilai $\mathrm{EC}_{50}$ kurang dari 50 ppm.

Aktivitas antioksidan yang baik pada ektrak metanol dapat dikorelasikan dengan hasil uji fitokimia. Hasil uji fitokimia menunjukkan bahwa ekstrak methanol $E$. spinosum mengandung golongan senyawa flavonoid, triterpenoid dan asam askorbat. Diduga berbagai golongan senyawa tersebut aktif dalam meredam radikal bebas (DPPH).

\section{Uji Aktivitas Antibakteri}

Uji aktivitas antibakteri dilakukan terhadap bakteri $S$. aureus (gram positif) dan $E$. coli (gram negatif) dengan variasi konsentrasi $30 \mathrm{mg} / \mathrm{mL}, 40 \mathrm{mg} / \mathrm{mL}, 50$ $\mathrm{mg} / \mathrm{mL}, 60 \mathrm{mg} / \mathrm{mL}, 70 \mathrm{mg} / \mathrm{mL}, 80 \mathrm{mg} / \mathrm{mL}$. Hasil uji aktivitas antibakteri ekstrak 
metanol ditunjukkan pada Tabel 5 dan Tabel 6.

Tabel 5 Hasil uji aktivitas antibakteri terhadap bakteri $E$. Coli

\begin{tabular}{|c|c|}
\hline $\begin{array}{c}\text { Konsentrasi ekstrak } \\
\text { metanol (mg/mL) }\end{array}$ & $\begin{array}{c}\text { Diameter } \\
\text { zona hambat } \\
(\mathbf{m m})\end{array}$ \\
\hline 30 & - \\
\hline 40 & - \\
\hline 50 & 1 \\
\hline 60 & 1 \\
\hline 70 & 2 \\
\hline 80 & 3 \\
\hline Total bakteri (CFU/mL) & $2,7 \times 10^{8}$ \\
\hline $\begin{array}{c}\text { Streptomisin } \\
(6,25 \text { mg/mL) }\end{array}$ & 13 \\
\hline Kontrol negatif (pelarut) & - \\
\hline
\end{tabular}

Tabel 6 Hasil uji aktivitas antibakteri terhadap bakteri $S$. aureus

\begin{tabular}{|c|c|}
\hline $\begin{array}{c}\text { Konsentrasi ekstrak } \\
\text { metanol (mg/mL) }\end{array}$ & $\begin{array}{c}\text { Diameter } \\
\text { zona hambat } \\
(\mathbf{m m})\end{array}$ \\
\hline 30 & - \\
\hline 40 & 1 \\
\hline 50 & 2 \\
\hline 60 & 2 \\
\hline 70 & 3 \\
\hline 80 & 4 \\
\hline Total bakteri (CFU/mL) & $1,8 \times 10^{8}$ \\
\hline Ampisilin & 22 \\
\hline (0,4 mg/mL) & - \\
\hline Kontrol negatif (pelarut) & \\
\hline
\end{tabular}

Hasil uji aktivitas antibakteri terhadap bakteri E. coli (Tabel 5) menunjukkan ekstrak metanol pada konsentrasi 30 $\mathrm{mg} / \mathrm{mL}$ dan $40 \mathrm{mg} / \mathrm{mL}$ tidak dapat memberikan daya penghambatan terhadap pertumbuhan bakteri E. coli. Hal ini kemungkinan disebabkan karena kandungan senyawa antibakteri yang terkandung dalam ekstrak metanol hanya sedikit sehingga pada konsentrasi 30 $\mathrm{mg} / \mathrm{mL}$ dan $40 \mathrm{mg} / \mathrm{mL}$ tidak dapat memberikan daya penghambatan terhadap pertumbuhan bakteri $E$. coli.

Aktivitas penghambatan ekstrak metanol terhadap pertumbuhan bakteri $E$. coli meningkat dengan semakin tingginya konsentrasi ekstrak yang ditunjukkan dengan semakin besarnya diameter zona bening di sekitar kertas cakram. Salah satu faktor penyebabnya yaitu senyawa aktif yang terdapat dalam ekstrak yang bersifat sebagai antibakteri semakin banyak dengan semakin tingginya konsentrasi ekstrak sehingga kemampuan ekstrak dalam menghambat pertumbuhan bakteri E. coli juga semakin besar.

Hasil uji aktivitas antibakteri terhadap bakteri S. Aureus (Tabel 6) menunjukkan bahwa kemampuan ekstrak metanol dalam menghambat pertumbuhan bakteri $S$. Aureus semakin bertambah besar dengan semakin bertambahnya konsentrasi ekstrak. Salah satu faktor penyebabnya ialah banyaknya komponen senyawa aktif yang bersifat antibakteri akan semakin banyak dengan semakin bertambahnya konsentrasi ekstrak sehingga diameter zona hambat akan semakin besar. Jika dibandingkan dengan kontrol streptomisin $6,25 \mathrm{mg} / \mathrm{mL}$ dengan daya hambat $13 \mathrm{~mm}$ dan ampisilin $0,4 \mathrm{mg} / \mathrm{mL}$ dengan daya hambat $22 \mathrm{~mm}$, maka ekstrak yang dihasilkan pada penelitian mempunyai daya hambat lebih kecil dari pada kontrol. Hal ini kemungkinan disebabkan karena terjadinya mekanisme resistensi bakteri terhadap senyawa antibakteri. Terjadinya resistensi dapat disebabkan oleh kemampuan bakteri dalam menghambat kerja senyawa antibakteri oleh mutasi yang kemungkinan bakteri untuk memintasi langkah-langkah peka yang dihambat oleh zat antibakteri, atau oleh mutasi yang menyebaban sel bakteri menjadi sulit untuk ditembus oleh bakteri (Volk dan Wheeler, 1993). Mekanisme resistensi bakteri ini juga dapat terjadi karena bakteri menurunkan permeabilitas dinding selnya sehingga senyawa antibakteri akan sulit masuk ke dalam sel. terjadinya resistensi bakteri menyebabkan terbentuknya beberapa populasi bakteri yang resisten sehingga zona hambat yang dihasilkan disekitar cakram semakin kecil. Akan tetapi, hal ini perlu dilakukan kajian lebih lanjut, yaitu dengan melakukan penelitian dengan variasi konsentrasi yang lebih luas karena 
ekstrak yang digunakan dalam penelitian ini merupakan ekstrak kasar dan belum dimurnikan.

Kontrol positif yang digunakan dalam penelitian ini adalah streptomisin ntuk $E$. coli dan ampisilin untuk $S$. aureus. Diameter zona hambat ampisilin dengan konsentrasi $0,4 \mathrm{mg} / \mathrm{mL}$ sebesar $22 \mathrm{~mm}$ dan diameter zona hambat streptomisin 6,25 $\mathrm{mg} / \mathrm{mL}$ adalah sebesar $13 \mathrm{~mm}$. Hal ini menunjukkan bahwa bakteri $S$. aureus yang digunakan pada penelitian ini tidak tergolong resisten terhadap kontrol ampisilin dengan menghasilkan zona hambat sebesar $22 \mathrm{~mm}$ karena bakteri $S$. aureus dapat dikatakan resisten apabila menghasilkan zona hambat kurang dari 20 mm. Begitu juga pada streptomisin untuk bakteri $E$. coli menghasilkan zona hambat $13 \mathrm{~mm}$. Hal ini menunjukkan bahwa bakteri E. coli yang digunakan pada penelitian ini tidak resisten terhadap streptomisin karena menghasilkan zona hambat sebesar $13 \mathrm{~mm}$. E. coli dapat dikatakan resisten terhadap streptomisin apabila menghasilkan zona hambat kurang dari $11 \mathrm{~mm}$.

Ekstrak metanol alga merah $E$. spinosum tetap dianggap mempunyai potensi sebagai antibakteri karena dapat menghambat pertumbuhan bakteri $S$. aureus pada konsentrasi $80 \mathrm{mg} / \mathrm{mL}$ sebesar $4 \mathrm{~mm}$ dan E. coli pada konsentrasi $80 \mathrm{mg} / \mathrm{mL}$ sebesar $3 \mathrm{~mm}$ yang ditunjukkan dengan adanya zona bening di sekitar cakram. Hal ini menunjukkan bahwa kekuatan senyawa antibakteri dalam ekstrak tersebut tergolong lemah.

Kontrol negatif digunakan untuk mengetahui apakah pelarut yang digunakan juga memiliki potensi menghambat bakteri. Kontrol negatif yang digunakan ialah metanol. Hasil penelitiaan menunjukkan bahwa kontrol negatif tidak memberikan zona hambat pada bakteri $S$. aureus dan $E$. coli. Hal ini bisa diasumsikan bahwa tidak ada pengaruh dari pelarut terhadap zona hambat yang diberikan oleh ekstrak.

\section{Identifikasi Golongan Senyawa Aktif}

Hasil identifikasi golongan senyawa aktif yang terdapat dalam ekstrak metanol alga merah $E$. spinosum ditunjukkan pada Tabel 7.

Hasil identifikasi menunjukkan bahwa ekstrak metanol mengandung golongan senyawa flavonoid, triterpenoid dan asam askorbat.

Tabel 7 Hasil identifikasi senyawa aktif estrak metanol alga merah (E. spinosum)

\begin{tabular}{l|c}
\hline Golongan Senyawa & $\begin{array}{c}\text { Ekstrak metanol alga } \\
\text { merah (E. spinosum) }\end{array}$ \\
\hline Flavonoid & +++ \\
Triterpenoid & ++ \\
Steroid & - \\
Alkaloid & - \\
- Mayer & - \\
- Dragendrof & + \\
Asam Askorbat & \\
\hline
\end{tabular}

Keterangan:

$+++=$ Kandungan senyawa lebih banyak (warna sangat pekat)

$++\quad=$ Mengandung senyawa (warna cukup pekat)

$+\quad=$ Mengandung senyawa (berwarna)

- $\quad=$ Tidak terkandung senyawa

Berbagai golongan senyawa yang terdapat dalam alga merah E. spinosum sangat berperan penting dalam pengujian aktivitas antioksidan dan antibakteri. Hasil pengujian aktivitas antioksidan menunjukkan bahwa sampel alga merah $E$. spinosum sangat aktif dalam menghambat oksidasi radikal bebas yang dapat menyebabkan berbagai penyakit seperti penuaan dini, arthritis dan kanker. Hal ini dapat dilihat dari nilai $\mathrm{EC}_{50}$ masing-masing fraksi yang berkisar antara 12-80 ppm yang menunjukkan alga merah E. spinosum memiliki aktivitas antioksidan yang sangat kuat, sehingga dari pengujian ini dapat diketahui bahwa alga merah ini memiliki manfaat yang sangat penting bagi kemaslahatan umat manusia terutama dalam bidang kesehatan masyarakat. 


\section{KESIMPULAN}

Ekstrak metanol alga merah $E$. spinosum mempunyai aktivitas antioksidan terhadap DPPH dengan nilai $\mathrm{EC}_{50}$ sebesar 22,13 ppm dan aktivitas antibakteri terhadap bakteri Staphylococcus aureus dan Escherichia coli dengan daya hambat pada konsentrasi $80 \mathrm{mg} / \mathrm{mL}$ secara berturut-turut sebesar $4 \mathrm{~mm}$ dan $3 \mathrm{~mm}$. Uji fitokimia ekstrak metanol alga merah E. spinosum menunjukkan adanya kandungan golongan senyawa flavonoid, triterpenoid dan asam askorbat.

\section{DAFTAR PUSTAKA}

AOAC. 1984. Official Methods of Analysis of the Association of Official Analitycal Chemist, Inc. Washington DC: Association of Offcial Analytical Chemists

Arindah, D. 2010. Fraksinasi dan Identifikasi Golongan Senyawa Antioksidan pada Daging Buah Pepino (Solonum Muricatum aiton) yang Berpotensi sebagai Antioksidan. Skripsi Tidak Diterbitkan. Malang: Jurusan Kimia Fakultas Sains dan Teknologi Universitas Islam Negeri (UIN) Maulana Malik Ibrahim Malang

Astawan, M., Muchtadi, D., Tutik, W., 2001. Pemanfaatan Rumput Laut pada Berbagai Makanan Jajanan Untuk Mencegah Timbulnya Defisiensi Iodium dan Penyakit Degeneratif. Laporan Penelitian. Bogor: IPB

Auterhoff, H., dan Kovar, K.A. 1987. Identifikasi Obat, Bandung: ITB

Enida, F. BR Naibaho, Ruth. 2011. Uji Aktivitas Antibakteri Fraksi n-heksana, Etilasetat dan Etanol Rumput Laut Coklat (Sargassum polycystum C.Agardh) terhadap bakteri Escherichia coli dan Staphylococcus aureus. Tugas Akhir Tidak Diterbitkan. Medan: Universitas Sumatera Utara.

Faten, M., Abou, E., and Emad, A.S. 2009. Antioxidant Activity of Extract and Semi-Purified Fractions of Marine Red Macroalga, Gracilaria Verrucosa. Australian. Journal of Basic and Applied Sciences. Kairo: Biochemistry Department, Faculty of Agriculture, Cairo University
Febriany, S. 2004. Pengaruh Beberapa Ekstrak Tunggal Bangle dan Gabungannya yang Berpotensi Meningkatkan Aktivitas Enzim Lipase Secara In Vitro. Skripsi tidak diterbitkan. Bogor: Fakultas MIPA IPB

Hudaya, S. dan Daradjat, S. 1981. Dasar-Dasar Pengawetan I. Departemen Pendidikan dan Kebudayaan, Jakarta

Indrayani, L., H. Soetjipto, dan L. Sihasale. 2006. Skrinning Fitokimia dan Uji Toksisitas Ekstrak Daun Pecut Kuda (Stachytarpheta jamaicensis L. Vahl) Terhadap Larva Udang Artemia salina Leach. Jurnal Fakultas Sains dan Matematika. Salatiga: Universitas Kristen Satya Wacana.

Iskandar, Yoppi. 2009. Uji aktivitas antibakteri ekstrak etanol rumput laut (Eucheuma cottonii) terhadap bakteri Escherichia coli dan Bacillus cereus. Sumedang: Jurusan Farmasi Fakultas MIPA Universitas Padjadjaran Jatinangor, Sumedang 45363.

Izzati, Munifa. 2007. Skreening Potensi Antibakteri pada Beberapa Spesies Rumput Laut terhadap Bakteri Patogen pada Udang Windu. Laboratorium Fungsi Tumbuhan. Vol. 9, No. 2. 62 67

Khazanda, K.A., Wazir, S.T.G., Samina, K., Shahzadi, S. 2007 et al. Antifungal Activity, Elemental Analysis And Determination of Total Protein Of Seaweed, Solieria robusta (Greville) Kylin From The Coast Of Karachi. National Center of Excellence for Aanalytical Chemistry. Pakistan: University of Sindh, Jamshoro-76080,

Kusumastanto, T. 2011. Pengembangan Sumberdaya Kelautan dalam Memperkokoh Perokonomian Nasional Abad 21. Tugas Akhir Tidak Diterbitkan. Bogor: Insitut Pertanian Bogor

Lestario, Ninan, L., Sugiarto, S., Timotius, K.H. 2008. Aktivitas antioksidan dan Kadar Fenolik Total dari Ganggang Merah (Gracilaria verucosa). Jurnal Teknologi dan Industri Pangan Vol XIX No 2. Salatiga: Universitas Kristen Satya Wacana.

Manilal. A., Sujith, S., Selvin, J., Kiran, G.S., Shakir, C. 2009. In vivo Antiviral Activity of Polysaccharide from the 
Indian Green Alga, Acrosiphonia orientalis (J. Agardh): Potential Implication in Shrimp Disease Management, Journal of Fish and Marine Sciences. Department of Microbiology. India: Bharathidasan University

Molyneux, P., 2003, The Use of The Stable Free Radical Diphenylpicrylhydrazyl (DPPH), for Estimating Antioxidant Activity. Journal of Science and Technology, Vol 26(2) : 211-219

Rahayu, D.S., Dewi, K., Enny, F. 2010. Penentuan Aktivitas Antioksidan dari Ekstrak Etanol Daun Ketapang (Terminalia catappa L) dengan Metode 1,1 difenil 2 Pikrilhidrazil (DPPH). Skripsi Diterbitkan. Semarang: Jurusan Kimia FMIPA Universitas Diponegoro.

Rahayu PW, Ma'oen S, Suliantari, Fardiaz S. 1992. Teknologi Fermentasi Produk Perikanan. Bogor: Departemen Pendidikan dan Kebudayaan, Direktorat Jenderal Pendidikan Tinggi, Pusat Antar Universitas Pangan dan Gizi, Institut Pertanian Bogor.

Romimuhtarto, K., dan Sri Juwana. 1999. Biologi Laut. Jakarta: Puslitbang Oseanologi LIPI.

Rosida dan Susiloningsih, E.K.B. 2007. Pengaruh Konsentrasi Starter Lactobacillus plantarum dan Lama Fermentasi Terhadap Kualitas dan Kerusakan Produk Terasi. Jurnal Protein: Vol.15 No.2

Setyowati A, Hidayati D, Awik PDN, Abdulgani N. 2009. Studi Histopatologi Hati Ikan Belanak (Mugil cephalu) di muara sungai Aloo Sidoarjo. Tugas Akhir Tidak Diterbitkan. Surabaya: Program Studi Biologi FMIPA, Institut Teknologi Sepuluh Nopember.

Soetan, K., Oyekunle, M., Aiyelaagbe, O., and Fafunso, M., 2006, Evaluation of The Antimicrobial Activity of Saponins Extract of Sorgum bicolor L. Moench, African Journal of Biotechnology, Vol 5 (23): 2405-2407.
Sudarmadji, S., B., Haryono, dan Suhardi. 2007. Analisis Bahan Makanan dan Pertanian. Yogyakarta: Liberty.

Volk.W.A dan Wheeler M.F 1993. Mikrobiologi Dasar. Markham. Jakarta: PT. Gelora Aksara Pratama.

Wibowo, S.T. 2001. Potensi Jenis-Jenis Rumput Laut dari Pantai Sayang Heulang-Pameungpeuk Garut Sebagai Antibakteri Escherichia coli. Jurnal Biologi. Bogor: Jurusan biologi, Institut Pertanian Bogor

Yuliani, D. 2011. Kajian Aktivitas Antioksidan Fraksi Etanol Jintan Hitam (Nigella sativa, L.). Skripsi Tidak Diterbitkan. Malang: Jurusan Kimia Fakultas Sains dan Teknologi Universitas Islam Negeri Maulana Malik Ibrahim Malang

Zakaria, Z.A., Zaiton, H., Henie, E.F.P., Jais, A. M.M., and Zainuddin, E.N.H., 2007, In Vitro Antibacterial Activity of Averrhoa bilimbi L. Leaves and Fruits Extracts, International Journal of Tropical Medicine, (Online), 2(3):96100,http://www.medwelljournals.com/fu 1ltext/ijtm/2007/96-100 .pdf, diakses 1 November 2011.

Zamrodi, Moh. 2011. Uji Fitokimia dan Uji Aktivitas Antibakteri Senyawa Aktif Tanaman Anting-anting (Acalypha indica L.). Tugas Akhir Tidak Diterbitkan. Malang: UIN Maulana Malik Ibrahim Malang.

Zandi, K., Saeed, T. Iraj, N., Zahra, R., Forough, Y., Samin, S., Kohzad, S. 2010. In Vitro Antitumor Activity of Gracilaria corticata (A Red Alga) Against Jurkat And Molt-4 Human Cancer Cell Lines. Journal of Biotechnology Bushehr Iran: University of Medical Sciences 